\title{
O ORDENAMENTO JURÍDICO FRENTE À QUESTÃO DO LIXO ELETRÔNICO: UMA ANÁLISE DA PROBLEMÁTICA NA CIDADE DE PORTO VELHO/RO ${ }^{1}$
}

\section{THE LEGAL SYSTEM AND THE ISSUE OF E-WASTE: AN ANALYSIS OF THE PROBLEM IN THE CITY OF PORTO VELHO/RO}

\author{
Xênia de Castro Barbosa² \\ João Baraldi Neto ${ }^{3}$ \\ José Italo Oliveira dos Santos ${ }^{4}$
}

\begin{abstract}
Resumo
O século XX consagrou o urbano como modo de vida, legando para o século XXI desafios complexos, dentre os quais, o da regulação acerca do lixo eletroeletrônico. No presente estudo buscamos analisar a situação do lixo eletrônico no município de Porto Velho evidenciando fatores históricos e geográficos que contribuíram para o cenário atual, bem como o ordenamento jurídico sobre o assunto. A pesquisa tem perfil qualitativo, foi desenvolvida com base no materialismo histórico-dialético e utilizou de documentos jurídicos e entrevistas como fontes. As interpretações dos dispositivos legais foram pautadas na Hermenêutica Jurídica e a análise das narrativas provenientes das entrevistas foi realizada com base na Análise do Discurso (AD). As entrevistas e imersões em campo tiveram grande significado para a conclusão do trabalho, pois possibilitaram integrar o Direito com a realidade social, evidenciando os limites de sua efetividade.
\end{abstract}

Palavras-chave: Cidade; Direito; Lixo Eletrônico; Consumo; Meio Ambiente.

\section{Abstract}

The XX century offered an urban lifestyle, giving to the XXI century multiple challenges, among which we can emphasize the legalization about the electronic wastes. The purpose of this article is to analyse the e-waste situation in Porto Velho highlighting the historical and geographical factors that have been contributing to the present scenario, including the legal system about the theme. This research has a qualitative side view, developed and based on historic-dialectic materialism and has used legal documents and interviews as instruments. All juridical interpretations were formed on Juridical Hermeneutics and Discourse Analysis. The interviews had immense significance to the conclusion of this article, as result of interaction between Right and society, highlighting limits of its consequences.

Keywords: City; Right; E-waste; Consumption; Environment.

\footnotetext{
${ }^{1} \mathrm{O}$ trabalho foi desenvolvido com recursos do CNPq e do IFRO, a quem registramos agradecimento.

2 Doutora em Geografia pela UFPR. Docente do Instituto Federal de Educação, Ciência e Tecnologia de Rondônia. Líder do Núcleo de Estudos e Históricos e Literários do IFRO. Bolsista de Extensão no país - EXP-C. E-mail: xenia.castro@ifro.edu.br

3 Técnico em Edificações pelo Instituto Federal de Educação, Ciência e Tecnologia de Rondônia. Acadêmico do curso de Direito da Faculdade Católica de Rondônia. Bolsista do CNPq - IC. E-mail: baraldi.n.j@gmail.com

4 Estudante do curso técnico em Química do Instituto Federal de Educação, Ciência e Tecnologia de Rondônia. Acadêmico de Direito da Universidade Federal de Rondônia. Bolsista do CNPq - IC. E-mail: italooliveira46@gmail.com
} 


\section{INTRODUÇÃO}

Este artigo resulta da pesquisa de Iniciação Científica intitulada "Cidade e Direito: uma análise da situação do lixo eletrônico em Porto Velho/RO", realizada entre 2015 e 2016, fomentada pelo CNPq. Foi desenvolvida no Núcleo de Estudos Históricos e Literários (NEHLI), do Instituto Federal de Educação, Ciência e Tecnologia de Rondônia (IFRO), na interface das linhas de pesquisa Gestão Ambiental do Território Urbano e História da Ciência e da Técnica. Os dois eixos de discussão perpassam as reflexões que deram suporte para o presente texto.

O Estudo teve como objetivo geral analisar a situação do lixo eletrônico no município de Porto Velho evidenciando os fatores históricos e geográficos que contribuíram para o cenário atual, considerando, ainda, o ordenamento jurídico sobre o assunto.

O Lixo eletrônico é um problema mundial que desafia as sociedades contemporâneas, basicamente por duas razões: (1) sua produção e descarte são crescentes, configurando um padrão de consumo exagerado, (2) é passível de poluição e contaminação do solo e de recursos hídricos, bem como de gerar doenças. Esses resíduos eletroeletrônicos possuem, frequentemente, metais pesados em sua composição.

Para discutir o embasamento jurídico do tema, incluímos outros tópicos como a relação de consumo no mundo globalizado, a cidade como direito fundamental e seu projeto utópico de construção, evidenciando as relações políticas decisivas para a ordem social e ambiental no espaço urbano.

Em Porto Velho, cidade amazônica que tem passado por acelerado processo de urbanização em função das obras do PAC - Programa de Aceleração do Crescimento, iniciadas em 2007, o ritmo de produção, consumo e descarte de RS - Resíduos Sólidos aumentou significativamente. Um dos fatores que contribuintes é o fato de a cidade sediar a construção de duas usinas hidrelétricas (Santo Antonio e Jirau), que geraram cerca de 50 mil empregos diretos e indiretos (FIERO, 2011). Ainda segundo o relatório da Federação das Indústrias do Estado de Rondônia (op. cit.), esta unidade da federação expressou, em 2011, a maior taxa de ocupação da população economicamente ativa da região Norte $(94,6 \%)$ e a segunda menor taxa de desemprego do Brasil, sendo que a maior parte desses empregos se concentrou em sua Capital. Se por um prisma essas obras resultaram em empregos e maior poder de consumo, por outro ocasionaram danos socioambientais de difícil, quiçá improvável resiliência. 
A população de Porto Velho, Capital do Estado é de aproximadamente 428 mil habitantes (IBGE, 2010), distribuída entre 66 bairros em perímetro urbano, três reservas indígenas (Karitiana, Kararaxi e Karipuna) e de 12 distritos na zona rural e ribeirinha, conforme pode ser observado na figura 1. O recorte empírico do estudo concentrou-se no perímetro urbano, em bairros das cinco zonas da cidade: Norte, Sul, Leste, Oeste e zona Central.

A produção crescente de RS, em geral e de lixo eletrônico, em particular é um problema presente não apenas em Porto Velho - recorte empírico que optamos estudar em função das transformações recentes pelas quais tem passado, como em todo o mundo. Trata-se de um problema típico da era moderna, que demanda estudos multidisciplinares urgentes com vistas à apresentação de propostas capazes de contribuir com a gestão ambiental do território urbano, a conservação dos recursos naturais necessários à vida e a salvaguarda do direito humano à cidade e ao meio ambiente equilibrado.

Diante do exposto, postula-se o Direito como ferramenta indispensável para a construção de uma ordem socioambiental mais justa. Essa ferramenta, todavia, encontra-se diante de novos desafios, que incidem na efetivação da justiça. Isso porque a mundialização da economia tem como face reversa o dano ambiental, e esses dois fatores incidem sobre o campo do Direito ocasionando crise na cultura jurídica e tencionando os modelos de fundamentação, de representação social e institucional (WOLKMER, 2013), estimulando a produção de novos paradigmas.

Nesse tempo em que "os direitos de propriedade privada e a taxa de lucro se sobrepõem a todas as outras noções de direito" (HARVEY, 2012, 73), faz necessária a retomada do conceito de direitos humanos, apreendido em sua concepção plural, e a luta por sua efetivação. É por esse prisma que buscamos pensar o direito à cidade e ao meio ambiente saudável, tomando em referência os desafios impostos pelo lixo eletrônico em Porto Velho/RO.

\section{METODOLOGIA}

A pesquisa desenvolvida apresenta perfil qualitativo e classifica-se, quanto aos objetivos, como Explicativa, e no que concerne aos procedimentos técnicos, como Exploratória (GIL, 2008). Realizou-se ainda revisão bibliográfico-documental, imersões em campo e registro de entrevistas semiestruturadas, com vistas a produzir informações sobre o problema.

O método adotado para o enfrentamento do problema foi o materialismo históricodialético (KONDER, 1981), centrado na observação da realidade social, com ênfase nas contradições, conflitos e dinâmicas históricas espacialmente engendradas.

Revista de Direito da Cidade, vol. 09, no 1. ISSN 2317-7721 pp. 276-312 278 
As fontes da pesquisa constituíram-se de resoluções, decretos, leis, relatórios e entrevistas. Dentre os documentos jurídicos, consideramos a Constituição Federal, em seu Art. 225 (BRASIL, 1988), que trata do meio ambiente, a Lei 12.305/2010 (BRASIL, 2010), que instituiu a Política Nacional de Resíduos Sólidos, a Lei 10.257, de 10 de julho de 2001 (BRASIL, 2001), conhecida como "Estatuto da Cidade", a Resolução CONAMA n. 257, de 30 de junho de 1999, que tratou do descarte e o gerenciamento ambientalmente adequado de pilhas e baterias usadas, a Resolução CONAMA n. 401/08 e de número. 263/99, e a Lei complementar 546/2014 (PORTO VELHO, 2014), que dispõe sobre a coleta regular e seletiva de resíduos sólidos no município, dentre outras.

Do ponto de vista empírico, foram feitas imersões em campo para observar a disposição do lixo eletrônico no espaço urbano de Porto Velho. Percorremos, de automóvel, toda a cidade, transitando pelas zonas central, norte, sul, leste e o Oeste e onde notamos presença de e-lixo, registramos fotografia e buscamos contato com os moradores das adjacências.

Além das observações registradas em caderno de campo e transpostas para editor de texto, foram registradas 15 entrevistas com moradores da cidade de Porto Velho, que residem em áreas expostas a presença de resíduos sólidos, em geral, e de lixo eletrônico, em particular. Cinco das entrevistas foram realizadas na região central de Porto Velho, no bairro conhecido como Triângulo. Nesse bairro notamos grande acúmulo de e-lixo próximo ao Mercado do Peixe, e por se tratar de uma região central abandonada, foi possível notar moradores de rua vivendo próximos a esse depósito. A existência de escritórios e prédios comerciais na área sugere que esses materiais sejam provenientes deles. Embora o bairro conte com serviço público de coleta de lixo, os moradores de rua se apropriam desses resíduos e passam a viver junto deles, talvez na expectativa de poder comerciá-los, algum dia.

Três entrevistas foram realizadas no Bairro Nova Esperança, na Zona Norte da cidade uma das áreas recentes de expansão urbana, onde se nota o avanço de condomínios fechados sobre áreas rurais e de floresta. Duas entrevistas foram registradas no Bairro Lagoinha, com moradores que ressentem da desvalorização da área em que residem em função dos vários tipos de lixos acumulados em terrenos baldios. Uma entrevista foi realizada no bairro Eletronorte, região sul de Porto Velho, uma no bairro Triângulo e três no bairro Marcos Freire. As entrevistas foram registradas conforme a disponibilidade dos moradores em participar da pesquisa e não se estabeleceu quantidade como critério amostral, dado o caráter qualitativo e exploratório do estudo. 
Utilizamos também de registros fotográficos produzidos pela equipe de pesquisa e de fotografias que nos foram cedidas pelo professor Saulo Gomes de Souza, a quem somos gratos. O estudo não teve como escopo operar análise de imagens, de modo que essas foram utilizadas para fins de comunicação visual do problema do lixo eletrônico em Porto Velho em seminários e eventos dos quais participamos e não serão apresentadas nesse artigo. Reconhecemos, todavia, a necessidade de estudos específicos sobre esse material iconográfico, o que pretendemos realizar em pesquisa futura.

Os documentos escritos foram analisados a partir de procedimentos de hermenêutica jurídica, tais como os elaborados por Gadamer (1997). Com base nessa ferramenta de análise foi possível compreender o significado mais profundo daquilo que está expresso no texto e na própria linguagem.

Consideramos a hermenêutica jurídica como: "um domínio teórico, especulativo, cujo objeto é a formulação, o estudo e a sistematização dos princípios e regras de interpretação do direito" (BARROSO, 2009, p. 107). Esses princípios e regras, segundo Gadamer (1997), devem atentar-se para casos concretos e realidades locais, de modo a não excluir das análises as especificidades sociais e históricas que conformam cada localidade, repercutindo no problema ao qual o Direito é convocado a intervir

Por meio da hermenêutica jurídica contrapomos as informações produzidas empiricamente (a partir do trabalho de campo no espaço urbano de Porto Velho) com as referências teóricas e jurídicas, buscando-se encontrar o justo meio e alcançar o consenso social para a interpretação da norma no caso concreto.

Acredita-se que o Direito enquanto área das Ciências Sociais Aplicadas deve discutir os fatores críticos sociais, principalmente os que carecem de regulamentação, pois há fatos cientificamente comprovados, além do método lógico de interpretação, que a sociedade muda constantemente e evolui gradativamente. A partir do método histórico-evolutivo, conforme Herkenhoff (2014) é possível entender a evolução jurídica e contribuir para que esta continue progredindo.

Considerou-se a hermenêutica jurídica como ferramenta capaz de assegurar objetividade e eficiência para análise da norma perante a subsunção real, e o Direito como instrumento de regulação das relações modernas, capaz ainda, de contribuir, em perspectiva educacional, para se evitar danos socioambientais, se aplicado de modo correto, em situações concretas, conforme propõem Gadamer: 
Uma lei não quer ser entendida historicamente. A interpretação deve concretizá-la em sua validez jurídica. Da mesma maneira, o texto de uma mensagem religiosa não deseja ser compreendido como um mero documento histórico, mas ele deve ser entendido de forma a poder exercer seu efeito redentor. Em ambos os casos isso implica que o texto, lei ou mensagem de salvação, se quiser compreendê-lo adequadamente, isto é, de acordo com as pretensões que o mesmo apresenta, tem de ser compreendido em cada instante, isto é, em cada situação concreta de uma maneira nova e distinta. Aqui, compreender é sempre também aplicar (GADAMER, 1997, p. 314).

Para ser entendida a lei pode passar por diversos processos de interpretação, mas deve ser aplicada na situação em que o problema se apresenta.

Herkenhoff (2004) elucida que:

A lei representa uma realidade cultural que se situa na progressão do tempo. Uma lei nasce, obedecendo a determinadas aspirações da sociedade ou da classe dominante da sociedade, traduzidas pelos que a elaboram, mas o seu significado não é imutável. É necessário verificar como a lei disporia se, no tempo de sua feitura, houvesse os fenômenos que se encontram presentes, no momento em que se interpreta ou aplica a lei[...] O processo históricoevolutivo considera que a lei não tem "conteúdo fixo, invariável, não pode viver para sempre imobilizada dentro de sua fórmula verbal, de todo impermeável às reações do meio, às mutações da vida. Tem de ceder às imposições do progresso, de entregar-se ao fluxo existencial, de ir evoluindo paralela à sociedade e adquirindo significação nova, à base das novas valorações". (HERKENHOFF, 2004, p. 15-16).

Como operadores da legislação e intérpretes, na falta da norma específica que regulamente o lixo eletrônico, o incluímos dentro da denominação de resíduos sólidos.

No que concerne à análise dos demais documentos que formaram o corpus documental do estudo (as entrevistas), esclarece-se que foram analisadas com o suporte da Análise do Discurso, especialmente com base em Foucault (1996, 2000) e Maziére (2007), que concordam que o discurso é acontecimento linguístico, que se expressa temporal e espacialmente a partir de condições, recursos e regras pré-acordadas, ainda que tacitamente, entre o emissor e o receptor.

Cientes de que "não se separa o enunciado nem de sua estrutura linguística, nem de suas condições de produção, de suas condições históricas e políticas, nem das interações subjetivas" (MAZIÉRE, 2007, p. 13), e de que seria impossível apresentar na íntegra, neste artigo, as entrevistas registradas, tomamos o cuidado de, sempre que necessário, explicitar o contexto de enunciação, de modo a evitar deturpações de sentido ou interpretações inadequadas.

A metodologia adotada mostrou-se adequada ao processo de investigação em tela. 


\section{PERSPECTIVAS TEÓRICAS}

Sem ter a pretensão de realizar exaustiva revisão literária, este tópico tem como propósito expressar considerações sobre os principais conceitos e categorias de análise que dizem respeito ao problema do lixo eletrônico em Porto Velho/RO.

A categoria "cidade" foi tomada como eixo de análise na proporção em que o problema investigado concentra-se, sobretudo, no espaço urbano, isso porque desde fins do século passado a cidade tem se destacado como lócus privilegiado da vida humana na Terra. O Relatório Perspectivas da Urbanização (ONU, 2014) revela que a população mundial residente em cidades, no ano de 2014, já ultrapassou a casa dos 3,9 milhões, e a expectativa é que esse número se eleve em pelo menos 50\%, até o ano de 2050. Assim é pertinente refletir não só sobre as formas e transformações urbanas, os problemas que reúne, como também seu sentido e significado humano.

Para Lúcia Lippi Oliveira (2002), a cidade é espaço público por excelência, e enquanto tal, expressa as contradições e divergência de interesse própria da vida coletiva. Embora contradições, conflitos e divergências devam ser equalizadas de modo a garantir o bem da maioria, a autora alerta que acidade deve estar aberta à comunicação entre os diferentes grupos sociais, as diferentes formas de expressão e usos do espaço, pois é justamente a diversidade que constitui um dos fatores de maior fascinação.

A vida urbana consagrou-se e ampliou sua escala com o desenvolvimento da modernidade e dos processos produtivos em moldes capitalistas. Nesse sentido, é pertinente refletir sobre a cidade considerando o conceito de modernidade. Para Bauman, 2005, esse é relevante na medida em que a modernização estabeleceu redes, fixos e fluxos que possibilitaram que o consumismo se acelerasse, e esse processo, além de transformar a vida das pessoas, parece irreversível: "não se dispõe mais de soluções globais para os problemas produzidos localmente, tampouco de escoadouros globais para excessos locais" (BAUMAN, 2005, p. 13).

Ao que sugere o autor, cada localidade deve encontrar mecanismos para enfrentar seus problemas, deve assumir a responsabilidade por sua esfera, o que não implica em abolir a solidariedade e o compartilhamento de boas práticas.

Embora a cidade seja o espaço de vida almejado cada vez mais pela maioria das pessoas, como atesta o êxodo rural, o acesso a ela tem sido frequentemente negado às populações mais pobres. Estas, no máximo alcançam uma inclusão incompleta, marginal, vivendo em suas franjas, 
em subempregos e submoradias, sem condições de desfrutar de todos os benefícios que a cidade oferece. A marginalidade social expressa nas cidades é indicativa de que o direito a ela está sendo sistematicamente negado.

Harvey (2012), que problematiza quanto à complexidade do direito à cidade, considerando-o como algo que vai além do simples acesso individual a recursos e equipamentos urbanos. Para ele, o direito à cidade tem se mostrado como um dos mais negligenciados direitos humanos, e essa negligência não diz respeito apenas às formas que cidade irá se expressar, sua estrutura, organização e redes, mas à maneira como os próprios seres humanos tem construído sua existência.

Ao colocar a questão urbana como direito humano negligenciado o autor intima os operadores do direito a mediar a relação entre Estado e Capital, de modo a salvaguardar os interesses coletivos e instiga a reflexão sobre as ações humanas no espaço. Dentre essas ações, o consumo recebe atenção especial:

[...] qualidade de vida urbana tornou-se uma mercadoria, assim como a própria cidade, num mundo onde o consumismo, o turismo e a indústria da cultura e do conhecimento se tornaram os principais aspectos da economia política urbana. A tendência pós-moderna de encorajar a formação de nichos de mercado - tantos hábitos de consumo quanto formas culturais - envolve a experiência urbana contemporânea com uma aura de liberdade de escolha, desde que se tenha dinheiro (HARVEY, 2012, p. 81).

A mercantilização da cidade e da qualidade de vida são, sem dúvidas, ameaças aos direitos humanos da atualidade, na medida em que são controlados por interesses privados.

Ainda conforme o autor (HARVEY, 2012), em face dos crescentes problemas urbanos, os Direitos Humanos estão sendo realocados diante de nova visão ética e política. Instituições, ONGs e pesquisadores vêm lutando arduamente para que estes sejam reconhecidos e aplicados mundialmente, de modo a reverter a sobreposição dos interesses corporativistas (seja do Estado, seja do grande Capital) sobre os direitos humanos. Nesses embates contra hegemônicos, a cidade tem ocupado papel de destaque, seja por ser o palco desses debates e ações, seja por ser o seu alvo. Afinal, é no espaço urbano que vive $54 \%$ da população mundial (ONU, 2014), e mesmo a população rural apresenta algum tipo de relação com o urbano. Embora apresentem especificidades que as distinguem, ambas se complementam e expressam interdependência (HESPANHOL, 2013).

Pethechust e Casimiro (2016), por sua vez, retomam a origem do conceito de "direito à cidade", localizando-o como desafio de superação das relações socioeconômicas estabelecidas no Capitalismo: 
O direito à cidade surge como um termo utilizado por urbanistas, filósofos, sociólogos e juristas, que identificam e reconhecem a presença do cidadão urbano como construtor e destinatário de um espaço que reproduz as características das relações socioeconômicas e jurídicas. A cidade se confunde com o próprio sistema econômico capitalista, de matiz industrial, no qual o ser humano é idealizador, protagonista e usufruidor. Em seu território convivem todas as necessidades e desigualdades socioeconômicas (PETHECHUST; CASIMIRO, 2016, p. 296-297).

As expressões "direito humano" e "direitos humanos" fazem referência

A proteção de maneira institucionalizada dos direitos da pessoa humana contra os excessos do poder cometidos pelos órgãos do Estado ou regras para se estabelecer condições humanas da vida e desenvolvimento da personalidade humana (UNESCO, 1978, p. 11, apud ÂNGELO, 1998, p. 17).

No Brasil, o instrumento mais conhecido de regulação do direito humano à cidade é a Lei $n$.

10.257, de 10 de julho de 2001 (BRASIL, 2002), conhecida como "Estatuto da Cidade". A referida Lei tem por preceito estabelecer "normas de ordem pública e de interesse social que regulam o uso da propriedade urbana em prol do bem coletivo, da segurança e do bem-estar dos cidadãos, bem como do equilíbrio ambiental" (Art. 1). Tem como diretrizes, dentre outras,

I - Garantia do direito a cidades sustentáveis, entendido como o direito à terra urbana, à moradia, ao saneamento ambiental, à infraestrutura urbana, ao transporte e aos serviços públicos, ao trabalho e ao lazer, para as presentes e futuras gerações [...]

$\mathrm{VI}$ - ordenação E controle do uso do solo, de forma a evitar:

a) a utilização inadequada dos imóveis urbanos;

b) a proximidade de usos incompatíveis ou inconvenientes [...]

f) a deterioração das áreas urbanizadas;

g) a poluição e a degradação ambiental [...]

VIII - adoção de padrões de produção e consumo de bens e serviços e de expansão urbana compatíveis com os limites da sustentabilidade ambiental, social e econômica do Município e do território sob sua área de influência;

Bauman $(2005,2007)$ contribuiu com este estudo na medida em que forneceu elementos para subsidiar reflexões sobre o modo de vida presente na contemporaneidade, e que expressa o tempo da modernidade e do consumo. O autor conceitua nosso tempo como um tempo líquido, de uma modernidade fluida, na qual os vínculos socioambientais são instáveis e voláteis, e as próprias relações humanas se revelam fragilizadas.

Em "Tempos Líquidos" (BAUMAN, 2007), discute como a globalização promoveu a interconexão e a abertura das sociedades a um padrão de consumo (seja de bens materiais, seja de bens culturais, como informação), que tende à homogeneidade. Simultaneamente, esse processo, ao tornar as sociedades abertas, trouxe consigo maior exposição e vulnerabilidade das pessoas, gerando novos temores sociais. 
Um dos principais fatores de impulso à globalização tem sido o desenvolvimento industrial de novas tecnologias. Essas têm se inserido de modo eficiente na sociedade, tornando a vida mais cômoda, todavia, sua face reversa assinala riscos ecológicos, além de um caráter excludente, na medida em que seu acesso é limitado a quem pode pagar por elas.

No que concerne aos riscos ambientais que se sobressaem na atual fase do capitalismo, estima-se apresentarem elevado potencial de impacto e capacidade de abrangência multiescalar, podendo afetar tanto áreas específicas, como um território em uma cidade, quanto o planeta, de modo abrangente. Ulrich Beck (2010) chega a designar a sociedade contemporânea como "sociedade de risco", argumentando quanto à premência de gestão política desses riscos.

Os impactos resultantes da globalização, da industrialização e da urbanização são amplos, e se fazem sentir de modo diferenciado nos diversos espaços, contudo, a cidade tem se revelado lócus privilegiado dos impactos negativos desse processo, em razão da densidade populacional e de ser, ela mesma, "a expressão territorial da socialização contraditória das forças produtivas no modo de produção capitalista" (SANTOS, 1982, p. 31).

É pertinente considerar que é próprio do capitalismo fomentar desenvolvimento geográfico desigual e combinado, que se expressa como condição e síntese dos processos de reprodução do capital, configurando "diferenciações, interações e relações tanto interescalares como intraescalares" (HARVEY, 2004, p. 112).

Globalização, industrialização e urbanização constituem, portanto, o tripé sobre o qual se sustenta o mundo contemporâneo.

Diante do cenário complexo engendrado pela interconexão da globalização, da industrialização e da urbanização crescente, afirma-se procedente a intervenção judicial tanto para salvaguardar os interesses individuais quanto o direito coletivo de acesso a um ambiente saudável. Não obstante, faz-se necessário que o município elabore e desenvolva, de modo eficaz, plano de gestão ambiental do território urbano que considere também os desafios impostos pelo lixo eletroeletrônico e outros elementos que configuram a vida moderna.

Do ponto de vista filosófico, precisamente da ética, entende-se necessária a reflexão sobre o modelo de consumo vigente, posto que a disponibilidade desses bens no mercado, a facilidade de crédito e a propaganda intensiva são fatores que tendem a favorecer ainda mais o consumo e, consequentemente, o descarte desses produtos no meio ambiente, quando já não atendem às necessidades e expectativas de seus consumidores. Além do que, raros são os pontos de coleta e raras as iniciativas de reuso ou reciclagem desses produtos, que rapidamente se tornam obsoletos.

Revista de Direito da Cidade, vol. 09, no 1. ISSN 2317-7721 pp. 276-312 285 


\section{RESULTADOS E DISCUSSÃO}

O lixo eletrônico (e-lixo) é um problema de viés socioambiental crescente em todo o mundo, tanto em países fortemente industrializados, como os Estados Unidos da América, como em países em desenvolvimento, que se encontram em fase de ampliação do consumo de bens materiais.

De acordo com Spitzcovsky (2013), a produção mundial de lixo eletrônico no ano de 2012 ultrapassou a marca de 48 milhões de toneladas, o que representa $7 \mathrm{~kg}$ de resíduos descartados por habitante. A principal parcela de contribuição foi dada pelos Estados Unidos, que gerou 9,4 milhões de toneladas, o que corresponde a 29,8 kg por habitante, seis vezes mais que a China, país que ocupa o segundo lugar. No continente americano, o segundo lugar no ranque dos que mais produziram lixo eletrônico foi ocupado pelo Brasil, que descartou mais 1,4 milhão de toneladas de e-lixo, o que segundo a autora (SPITZCOVSKY, op. cit), corresponde à média global de $7 \mathrm{~kg}$ por habitante.

Não foi possível precisar a quantidade de resíduos eletrônicos descartados em Porto Velho, por outro lado, a pesquisa revelou informações qualitativas interessantes acerca do problema. Foinos dado perceber que a cidade sofre danos ambientais, que a gestão municipal não dispõe de mecanismos eficientes de controle sobre o lixo eletroeletrônico e que esse causa profundos impactos sobre a vida social de seus moradores. Essas constatações foram feitas durante o trabalho de campo e o trabalho analítico, conforme demonstraremos a seguir. Na demonstração procuraremos intercalar as percepções dos entrevistados com as previsões legais e as interpretações que tecemos a seu respeito.

A entrevistada, aqui chamada de M.C.N, funcionária pública, moradora do Bairro Nova Esperança, situado na Zona Norte de Porto Velho, nos relatou as experiências que passa no dia-adia convivendo nas proximidades de um terreno com atividades irregulares, neste caso específico, um depósito de resíduos sólidos, dentre os quais lixo eletroeletrônico.

No momento mesmo da entrevista, notou-se o aparecimento de um animal peçonhento. Segundo a entrevistada, os bichos são provenientes do lixo que cerca sua residência. Revelou:

Deus me livre, tenho medo desse bicho aí mais do que não sei o que... Aqui já apareceu acho que umas duas dessas aqui. E o dono desse terreno aí, ele veio capinar aqui e matou duas cobras. Isso dentro da cidade. E aí fica difícil para a gente (M.C.N. Entrevista concedida a João Baraldi Neto, 2016).

Mas os animais peçonhentos não são os únicos problemas enfrentados por Dona M. C. N. Em sua entrevista revelou dificuldades enfrentadas há mais de 20 anos, relacionadas a um projeto 
de urbanização incompleto e à omissão do poder público frente aos problemas mais urgentes do bairro, como o saneamento básico, a iluminação pública e a distribuição de água potável.

As zonas periféricas de Porto Velho, distante do centro histórico, político e administrativo da cidade, foram se formando a partir de loteamentos de antigas fazendas e neles coexistem equipamentos e práticas que mesclam o rural e o urbano, e em muitos casos, a sobrevivência desses elementos rurais se dá mais por necessidade e falta de opção do que por escolha voluntária dos cidadãos. Destarte, essas regiões caracterizam-se tanto como periferia geográfica, de onde o Estado está distante, como periferia social, únicos redutos aos quais foi possível o estabelecimento de migrantes e trabalhadores de condição econômica mais vulnerável. Percebe-se, dessa forma, que o processo histórico de formação da cidade vem ocorrendo de modo desordenado, ocasionando insegurança e desconforto em sua população. A entrevistada destacou o medo de animais peçonhentos, que adentram em sua residência em função de haver depósito de lixo do tipo "ferro velho" no terreno ao lado. Poderia, todavia, ter citado outros medos, como o da falta de segurança, uma vez que há pouco policiamento no bairro Nova Esperança e é ele formado por grande quantidade de terrenos baldios e com resquícios de floresta - o que pode servir como esconderijo ou base de ação de criminosos.

Outro entrevistado, morador do bairro Triângulo, relatou os sérios problemas de saúde que enfrentou nos anos de 2013 e 2014, problemas que ele atribui à concentração de lixo próximo à sua residência.

Moro entre a cidade e a floresta, digamos assim, e lá tem muito lixo depositado. As pessoas da cidade jogam lixo lá, porque acham que é o fim da cidade... Lugar de terrenos baldios... Por outro lado, as pessoas de lá, meus vizinhos, também acumulam lixo, inclusive lixo eletrônico, pilha, bateria, celular velho, porque não tem coleta. Por causa disso [problema do lixo] passei praticamente dois anos doente, sem ter força pra nada. Tive dengue e malária, uma seguida da outra. Sofri muito, pensei que fosse morrer. (R. R. S. Entrevista concedida a Xênia de Castro Barbosa, 2015).

O morar "entre a cidade e a floresta" é elucidativo do processo histórico de urbanização da cidade de Porto Velho. Nesta cidade o urbano avança sobre a floresta, comprometendo ecossistemas e, ao mesmo tempo, não se efetiva de modo completo, seja em razão da força pujante da floresta amazônica, que insiste em se reerguer, seja em função da resistência própria da cultura tradicional de seus habitantes indígenas, caboclos e ribeirinhos. Para esses, a vida na cidade é conflituosa e desagregadora, razão pela qual tentam manter práticas antigas que the dão a sensação de continuidade cultural. Essas populações, que consumiam alimentos provenientes do 
rio ou da floresta, jogavam os restos próximos a casa - e esses resíduos orgânicos serviam de adubo para fertilizar o solo, onde plantavam pequenas hortas e jardins de plantas medicinais.

Expulsos de seu espaço tradicional em função do processo de colonização e exploração dos recursos madeireiros e minerais, esses agora moradores da cidade não sabem ao certo como viver nesse novo espaço e continuam a jogar o lixo próximo de suas casas. A diferença é que o tipo de lixo que é descartado agora é poluente e pouco biodegradável, resultante de processos industriais, podendo inclusive favorecer a proliferação de vetores propagadores de doenças.

O entrevistado destaca em sua narrativa a negligência da sociedade e do poder público quanto aos cuidados com o lixo e nos instiga a pensar, inclusive, que esteja ocorrendo falha do poder público no que diz respeito ao inciso $V$ do Artigo 225 da CF, a saber, a competência de controlar a produção, a comercialização e o emprego de técnicas, métodos e substâncias que comportem risco para a vida, a qualidade de vida e o meio ambiente. O inciso supracitado foi regulamentado pela Lei n. 11.105, de 24 de março de 2005 (BRASIL, 2005), todavia, a regulamentação novel (op. cit.) deixou passar os desafios causados pelo lixo eletrônico, centrando seus esforços em estabelecer normas e mecanismos de fiscalização das atividades que envolvam organismos geneticamente modificados (OGM), como se apenas estes fossem capazes de impetrar danos à biossegurança e ao equilíbrio ambiental.

O problema do lixo eletrônico é tratado de forma direta e indireta pela legislação brasileira e consideramos que o tratamento indireto, difuso e pouco incisivo contribui para a permanência e agravamento do problema. Em pesquisa no site do CONAMA localizou-se poucos instrumentos que dispõem sobre o assunto, a saber, a Resolução CONAMA n. 452, de 2 de julho de 2012, que dispôs sobre os procedimentos de controle da importação de resíduos, conforme as normas adotadas pela Convenção da Basiléia sobre o Controle de Movimentos Transfronteiriços de Resíduos Perigosos e seu Depósito; e a Resolução CONAMA n. 257, de 30 de junho de 1999, que tratou do descarte e gerenciamento ambientalmente adequado de pilhas e baterias usadas, no que reporta à coleta, reutilização, reciclagem, tratamento ou disposição final. Esta resolução, todavia, foi revogada nove anos depois, pela Resolução n. 401/2008 e alterada pela Resolução n. 263/1999, que acrescentou o inciso IV no art. 6‥

A existência dessas resoluções é importante porque representa um esforço do Conselho Nacional de Meio Ambiente em regular o problema de alguns tipos de e-lixo e indica o reconhecimento, por parte desse órgão, de que existem componentes eletroeletrônicos 
prejudiciais à saúde e ao meio ambiente. O reconhecimento do problema é o primeiro passo para seu enfrentamento.

Em respeito à Resolução CONAMA n. 452/2012, destaca-se que esta não faz menção ao termo "lixo eletrônico", mas considera esse tipo de lixo sob a égide das noções de "resíduos sólidos" e "resíduos perigosos". O texto não especifica o significado de resíduos sólidos, talvez por supor que já exista conhecimento consensual sobre o assunto. No Brasil, os resíduos sólidos foram definidos como aqueles que:

Resultam de atividades de origem industrial, doméstica, hospitalar, comercial, agrícola, de serviços e de varrição. Ficam incluídos nesta definição os lodos provenientes de sistemas de tratamento de água, aqueles gerados em equipamentos e instalações de controle de poluição, bem como determinados líquidos cujas particularidades tornem inviável o seu lançamento na rede pública de esgotos ou corpos de água, ou exijam para isso soluções, técnica e economicamente, inviáveis em face à melhor tecnologia disponível (ABNT, 2004)

Por outro lado, a Resolução CONAMA n. 452/2012 conceitua "resíduos perigosos":

Art. 2ㅇ Para efeitos desta Resolução serão adotadas as seguintes definições: I - Resíduos Perigosos - Classe I: são aqueles que se enquadrem em qualquer categoria contida no Anexo I, a menos que não possuam quaisquer das características descritas no Anexo III, bem como os resíduos listados nos Anexos II e IV.

O Anexo I da referida Resolução apresenta uma lista com 45 itens considerados perigosos para a saúde humana e ambiental, dentre os quais alguns que se fazem presentes em equipamentos eletroeletrônicos, como compostos de cobre e zinco, mercúrio, chumbo e tálio.

Dentre as proibições impostas pela Resolução CONAMA em análise constam: (1) os resíduos perigosos - Classe I e rejeitos, "em todo o território nacional, sob qualquer forma e para qualquer fim" (Art. 3(ํㅡㄹ conforme determina, também, a Lei n. 12.305, de 2 de agosto de 2010; (2) os resíduos definidos como "Outros Resíduos", sob qualquer forma e para qualquer fim (Art. 4으). Por "Outros Resíduos" a Resolução entende os coletados de residências ou os oriundos de sua incineração (Art. 2ำ, inciso IV).

As proibições acima se postam contra a atitude de países, Estados e empresas que, ao invés de buscar meios para solucionar o problema do lixo existente em seus próprios territórios, os enviam para áreas periféricas (em geral países pobres), transferindo a responsabilidade sobre o problema. Muitas vezes esse lixo é transferido sob a forma de doação e está contaminado em razão de manejo incorreto, e os recebedores acreditam em poder reciclá-lo e se beneficiar de algum modo. 
No que tange à Resolução CONAMA n. 401/2008, destaca-se seu valor educativo, além do regulatório que Ihe é implícito. A Resolução apresenta de forma didática e em linguagem acessível, em suas disposições gerais, os conceitos básicos de pilha, acumulador, bateria, pilha botão, pilha miniatura, bem como o que entende por destinação ambientalmente adequada, reciclador e importador. Define os limites máximos de chumbo, cádmio e mercúrio para pilhas e baterias comercializadas no território nacional e os critérios e padrões para o seu gerenciamento ambientalmente adequado.

O caráter educativo dessa Resolução é enfatizado em seu Capítulo V, intitulado, "Da informação, educação e comunicação ambiental", que assim instrui:

Art. 14. Nos materiais publicitários e nas embalagens de pilhas e baterias, fabricadas no País ou importadas, deverão constar de forma clara, visível e em língua portuguesa, a simbologia indicativa da destinação adequada, as advertências sobre os riscos à saúde humana e ao meio ambiente, bem como a necessidade de, após seu uso, serem encaminhadas aos revendedores ou à rede de assistência técnica autorizada, conforme Anexo I. Art. 15. Os fabricantes e importadores de produtos que incorporem pilhas e baterias deverão informar aos consumidores sobre como proceder quanto à remoção destas pilhas e baterias após a sua utilização, possibilitando sua destinação separadamente dos aparelhos.

Parágrafo único. Nos casos em que a remoção das pilhas ou baterias não for possível, oferecer risco ao consumidor ou, quando forem parte integrante e não removíveis do produto, o fabricante ou importador deverá obedecer aos critérios desta Resolução quanto à coleta e sua destinação ambientalmente adequada, sem prejuízo da obrigação de informar devidamente o consumidor sobre esses riscos.

Ao se observar algumas pilhas e baterias disponíveis no mercado pôde-se perceber que fabricantes tem cumprido a Resolução CONAMA 401/2008 e promovido inclusive uma comunicação visual, capaz de esclarecer ao consumidor sobre como proceder com esses materiais poluentes. Por outro lado, quando visitamos estabelecimentos distribuidores desses produtos no mercado de Porto Velho, constatamos apenas duas empresas que possuem dispositivo para recolhimento das pilhas e baterias usadas, e um órgão público, o Instituto Federal de Educação, Ciência e Tecnologia de Rondônia que possui projeto institucional próprio que opera a coleta de pilhas e baterias usadas e sua reciclagem. O projeto também promove palestras educativas sobre 0 cuidado com o meio ambiente.

Para moradores, gestores públicos e profissionais da saúde entrevistados durante esta pesquisa, o acúmulo de resíduos sólidos foi reconhecido como um dos principais responsáveis pelos elevados casos de endemias tropicais existentes no município: 
A dengue é uma doença que está em todos os lugares, inclusive em bairros centrais, mas nos bairros com índices mais elevados de infestação observamos o problema do lixo: $50 \%$ dela está no lixo urbano, 50\% está dentro da nossa casa. Então, as pessoas, não têm o cuidado de limpar o seu quintal... (D. S. Entrevista concedida a Xênia de Castro Barbosa, 2014).

O problema do lixo relaciona-se à cultura individual, mas também é de responsabilidade do Poder Público, assim, ambas as partes devem zelar para que não comprometa a sanidade do meio ambiente.

O meio ambiente equilibrado é direito de todos, previsto no Artigo 225 da Constituição Federal (BRASIL, 1988), que o reconhece como bem de uso comum do povo e essencial à sadia qualidade de vida. Por possuir valor essencial à vida o poder constituinte impôs tanto ao Poder Público quanto à coletividade o dever de defendê-lo e preservá-lo para as gerações contemporâneas e as futuras.

A Resolução CONAMA n. 263, de 12 de novembro de 1999 contém um texto bem curto, com apenas dois artigos, sendo o segundo de estabelecimento de sua vigência e o primeiro de alteração do Artigo 6o da Resolução CONAMA n. 257/99. Esse primeiro Artigo da Resolução CONAMA n. 263, de 12 de novembro de 1999 especifica que as pilhas do tipo miniatura e botão podem ter até $25 \mathrm{mg}$ de mercúrio por elemento. Não apresenta nenhuma instrução sobre como deve ser feito o descarte após o uso e se alguma forma de reuso é recomendada.

Embora o mercúrio tenha recebido atenção por parte da Resolução acima referida, outros elementos presentes no lixo eletroeletrônico permaneceram sem receber considerações e sem dosagem da quantidade limite dos elementos potencialmente prejudiciais ao meio ambiente e à saúde, caracterizando omissão.

A Lei 12.305, de dois de agosto de 2010 (BRASIL, 2010), que instituiu a Política Nacional de Resíduos Sólidos também não apresentou informações suficientes sobre o lixo eletrônico em particular. Apesar dessa limitação, reconhecemo-la como instrumento significativo para a gestão ambiental, e destacamos como pontos positivos o fato de integrar a Política Nacional do Meio Ambiente e articular-se com a Política Nacional de Educação Ambiental.

Em suas disposições gerais o texto legal esclarece que,

Art. 4o - A Política Nacional de Resíduos Sólidos reúne o conjunto de princípios, objetivos, instrumentos, diretrizes, metas e ações adotados pelo Governo Federal, isoladamente ou em regime de cooperação com Estados, Distrito Federal, Municípios ou particulares, com vistas à gestão integrada e ao gerenciamento ambientalmente adequado dos resíduos sólidos (BRASIL, 2010) 
Dentre os objetivos apresentados, a lei supracitada (BRASIL, 2010) tem como escopo, conforme expresso em seu Art. 7으

I - Proteção da saúde pública e da qualidade ambiental;

II - Não geração, redução, reutilização, reciclagem e tratamento dos resíduos sólidos, bem como disposição final ambientalmente adequada dos rejeitos; III - estímulo à adoção de padrões sustentáveis de produção e consumo de bens e serviços;

IV - adoção, desenvolvimento e aprimoramento de tecnologias limpas como forma de minimizar impactos ambientais;

$\checkmark$ - Redução do volume e da periculosidade dos resíduos perigosos;

$\mathrm{VI}$ - Incentivo à indústria da reciclagem, tendo em vista fomentar o uso de matérias-primas e insumos derivados de materiais recicláveis e reciclados;

VII - gestão integrada de resíduos sólidos;

VIII - articulação entre as diferentes esferas do poder público, e destas com o setor empresarial, com vistas à cooperação técnica e financeira para a gestão integrada de resíduos sólidos;

IX - Capacitação técnica continuada na área de resíduos sólidos;

$X$ - regularidade, continuidade, funcionalidade e universalização da prestação dos serviços públicos de limpeza urbana e de manejo de resíduos sólidos, com adoção de mecanismos gerenciais e econômicos que assegurem a recuperação dos custos dos serviços prestados, como forma de garantir sua sustentabilidade operacional e financeira, observada a Lei ㄲo 11.445 , de 2007;

$\mathrm{XI}$ - prioridade, nas aquisições e contratações governamentais, para:

a) produtos reciclados e recicláveis;

b) bens, serviços e obras que considerem critérios compatíveis com padrões de consumo social e ambientalmente sustentáveis;

XII - integração dos catadores de materiais reutilizáveis e recicláveis nas ações que envolvam a responsabilidade compartilhada pelo ciclo de vida dos produtos;

XIII - estímulo à implementação da avaliação do ciclo de vida do produto;

XIV - incentivo ao desenvolvimento de sistemas de gestão ambiental e empresarial voltados para a melhoria dos processos produtivos e ao reaproveitamento dos resíduos sólidos, incluídos a recuperação e o aproveitamento energético;

$X V$ - Estímulo à rotulagem ambiental e ao consumo sustentável.

Esses objetivos, dado seu caráter abrangente e a complexidade para serem alcançados

correm o risco de se tornarem "letra morta" se não forem estabelecidas medidas precisas para implementá-los. Lamenta-se ainda a falta de direcionamento e incentivos ao consumidor. Apesar de ser um avanço para o ordenamento jurídico, tendo em vista os longos anos até a sua elaboração, ainda assim, concorda-se com Pethechust e Casimiro (2016):

Conclui-se que a Lei $n^{\circ} .12 .305 / 2010$, em que pese representar um importante avanço no tocante ao problema dos resíduos sólidos no país, pecou em não estabelecer um rol de instrumentos de incentivo voltados ao consumidor, o que 
prejudica e coloca em risco o desenvolvimento socioambiental nas cidades (PETHECHUST; CASIMIRO, 2016, p. 303).

Outro ponto crítico é o atraso na consecução e avaliação de seus objetivos. Seu Art. 15 afirma que o Plano Nacional de Resíduos Sólidos (BRASIL, 2010) terá vigência por prazo indeterminado e horizonte de 20 (vinte) anos, a ser atualizado a cada quatro anos, tendo como conteúdo mínimo:

I - Diagnóstico da situação atual dos resíduos sólidos;

II - Proposição de cenários, incluindo tendências internacionais e macroeconômicas;

III - metas de redução, reutilização, reciclagem, entre outras, com vistas a reduzir a quantidade de resíduos e rejeitos encaminhados para disposição final ambientalmente adequada;

IV - Metas para o aproveitamento energético dos gases gerados nas unidades de disposição final de resíduos sólidos;

V - Metas para a eliminação e recuperação de lixões, associadas à inclusão social e à emancipação econômica de catadores de materiais reutilizáveis e recicláveis;

VI - programas, projetos e ações para o atendimento das metas previstas;

VII - normas e condicionantes técnicas para o acesso a recursos da União, para a obtenção de seu aval ou para o acesso a recursos administrados, direta ou indiretamente, por entidade federal, quando destinados a ações e programas de interesse dos resíduos sólidos;

VIII - medidas para incentivar e viabilizar a gestão regionalizada dos resíduos sólidos;

IX - Diretrizes para o planejamento e demais atividades de gestão de resíduos sólidos das regiões integradas de desenvolvimento instituídas por lei complementar, bem como para as áreas de especial interesse turístico;

$X$ - normas e diretrizes para a disposição final de rejeitos e, quando couber, de resíduos;

XI - meios a serem utilizados para o controle e a fiscalização, no âmbito nacional, de sua implementação e operacionalização, assegurado o controle social.

Sem adentrar no mérito do caráter obscuro relativo a um "prazo de validade indeterminado e horizonte de 20 anos", nem mesmo as metas têm sido quantificadas e qualificadas, quem dirá as ações para alcançá-las. Além do que, já se passaram seis anos desde a promulgação da Lei 12.305/2010 e os procedimentos de revisão previstos em seu Artigo 15 ainda não foram publicados.

Revisões periódicas nos instrumentos jurídicos e nas políticas e programas nacionais se fazem necessário, tendo em vista que a realidade social é dinâmica e suas transformações incidem sobre o meio em que vive. Tendo como base o inciso IV e posteriores da referida lei, faz-se necessário discutir a proposição de eliminação dos lixões, no ano de 2014, conforme 
planejamento. Ao se rever objetivos e ações, é possível definir novas estratégias, mais condizentes com o cenário de atuação.

Um dos desafios da Lei 12.305/2010 era o de extinguir os lixões até dois de agosto de 2014, no entanto, esse objetivo não foi plenamente alcançado e o debate em torno dessa questão parece ter se extinguido. Os prefeitos municipais, ao contrário do que afirmou a então ministra do Meio Ambiente, Senhora Isabella Teixeira, tem preferido manter "um lixão em seus quintais" (ARAÚJO, 2014). Fazem-se necessários novos estudos sobre esse problema, de modo a promover a compreensão pública sobre o porquê os municípios não terem conseguido erradicar os lixões e construir aterros sanitários ambientalmente adequados.

A permanência de lixões a céu aberto contribui não só para prejuízos ao meio ambiente, mas também para prejuízos humanos e sociais. Frequentemente, onde há lixões há pessoas vivendo do lixo, e não nos reportamos exclusivamente aos catadores que obtém renda com a reciclagem ou comercialização desses descartes, mas às pessoas que ultrapassaram a linha da miséria e retiram do lixo os alimentos necessários à sua sobrevivência. Tais pessoas ainda existem em nossa sociedade - embora pareçam invisíveis para muitos.

Em Porto Velho 350 famílias vivem na Vila Princesa, uma comunidade que é o oposto de qualquer conto de fadas. Essa comunidade se formou dentro do lixão municipal, do qual a maioria dos moradores extrai os víveres para a sobrevivência diária. Trata-se de uma área degradada, onde pessoas convivem com a miséria, expostas a riscos diversos, doenças e a humilhação social. Sujeitas inclusive à contaminação por componentes químicos presentes em lixo eletrônico.

Salienta-se que o município de Porto Velho não dispõe de coleta seletiva e de nenhuma instrução específica sobre como e onde descartar o lixo eletroeletrônico. Não informa sobre possibilidades de tratamento, reutilização ou reciclagem. Isso porque a Lei Complementar n. 546/2014 - que trata desse assunto - ainda não foi regulamentada. A Prefeitura alegou dificuldades nos processos licitatórios e falta de recursos para fazer as adequações requeridas pelo instrumento, mas não respondeu à solicitação de entrevista que enviamos via ofício.

A existência da comunidade da Vila Princesa, no espaço do lixão, assim como de outras comunidades humanas, residentes em áreas adjacentes a depósitos de inservíveis são exemplos claros de que está havendo inobservância do que rege a Lei 12.305/2010. O Artigo 48 desta Lei interdita as seguintes atividades:

Art. 48. São proibidas, nas áreas de disposição final de resíduos ou rejeitos, as seguintes atividades:

I - Utilização dos rejeitos dispostos como alimentação; 
II - Catação, observado o disposto no inciso V do art. 17;

III - criação de animais domésticos;

IV - Fixação de habitações temporárias ou permanentes;

Essas atividades, contudo, ocorrem diariamente no lixão localizado na Vila Princesa, em Porto Velho, são também parcialmente realizadas nos bairros onde realizamos trabalho de campo e registramos as entrevistas.

Retomando as narrativas dos entrevistados, o senhor R. R. S revela a negligência da sociedade (moradores) e do Poder Público (Prefeitura) no descarte e coleta do lixo. Já a fala do senhor D. S, enfatiza o comportamento individual, ao que é preciso esclarecer, com base no contexto, que não se tratou de simples defesa do poder municipal do qual era representante, mas de um chamamento da sociedade para efetuar ações pontuais de combate à dengue, como a limpeza do quintal da casa onde moram.

Outro médico e gestor de saúde entrevistado esclareceu:

Em minha opinião esses são os males atuais: cidades grandes, inchadas, sem planejamento, e na maioria das vezes gestões públicas ineficientes, principalmente nas áreas primárias, áreas básicas como infraestrutura e saneamento básico. (S. B. Entrevista concedida a Xênia de Castro Barbosa, 2013).

Embora pareça consensual a gravidade do problema dos RSU, em geral, e do lixo eletrônico, em particular, persistem a falta de planejamento e gestões ineficientes do ponto de vista da sanidade ambiental, assim como a falta de informações sobre o assunto. Os problemas evidenciados pelo entrevistado sugerem que em Porto Velho a Lei n. 10.257, de 10 de julho de 2001 (BRASIL, 2002) não tem se efetivado, especialmente porque a ordenação do solo e a adoção de padrões de produção, consumo e expansão urbana não têm sido procedidas em conformidade com os limites da sustentabilidade ambiental, social e econômica, conforme previsto no inciso VIII da referida Lei.

Segundo relatos dos moradores do bairro Nova Esperança diversas denúncias foram feitas sobre o problema do depósito de lixo existente naquele bairro, porém, os órgãos responsáveis pela fiscalização e controle não efetuaram as devidas notificações e, ao que consta, sequer se deslocaram para verificar in loco o problema. Conforme o Art. 29 da Lei 12.305/2010, o poder público tem a obrigatoriedade de atuar subsidiariamente, com vistas a minimizar ou cessar o dano, logo que tome conhecimento de evento lesivo ao meio ambiente ou à saúde pública. Na interpretação dos entrevistados essa atuação esperada por parte do Estado não está ocorrendo. Os entrevistados efetuam, portanto, uma crítica contumaz. 
Os efeitos dos componentes químicos presentes no lixo eletroeletrônico sobre a saúde humana e o meio ambiente são pouco conhecidos dos entrevistados, contudo, sabem de modo genérico, que "são poluidores e podem causar problemas de saúde".

Isso aí é o seguinte, ele afeta muitas pessoas. O que afeta mais são essas baterias. Esses materiais afetam até o lençol freático. Rapaz, eu falei com um cara aí, que disse que nossa água já tá contaminada. Ele é biólogo, tem um terreno aqui (E.N. Entrevista concedida a João Baraldi Neto, 2016).

Uma das consequências mais diretas percebidas foi a proliferação de mosquitos transmissores de doença, pois esses equipamentos podem acumular água de chuva.

Pode até contribuir porque nasce na água, aí tem muita água empossada, eu acho que fica, tem muita coisa que fica aí, pode juntar muito lixo. Quando eu cheguei aqui, isso era um matagal, meu filho pegou malária e morreu por causa disso, meu filho mais velho. Esse aí (E.N) foi internado bem umas três vezes. Aqui tem muito mosquito, isso eu não vou negar não. Se você ficar aqui até $(18 \mathrm{H})$ você não aguenta de tanto carapanã. (M.C.N. Entrevista concedida a João Baraldi Neto, 2016).

A presença de depósitos de lixo no Bairro Nova Esperança, Mocambo e Lagoinha também foram percebidos pelos moradores entrevistados como fator de depreciação das qualidades estéticas do ambiente, de desvalorização econômica de seus bens patrimoniais, bem como de obstáculos a determinados trabalhos que desejam realizar.

Com certeza enfeia a cidade e dá uma aparência de abandono ao bairro. Quem vê pensa que todo mundo é sujo, gosta da sujeira. Todo mundo que convive com isso, porque tá na rua, tá na beira da rua, né? [...]. Se você quiser vender uma casa, a pessoa já vem e coloca o preço lá embaixo, só porque tem esse problema do lixo, então, com certeza isso atrapalha a nossa vida (C. R. O. S. Entrevista concedida a Xênia de Castro Barbosa, 2016).

Para o senhor F. F. A., a presença de lixo em seu bairro interdita de forma direta o direito econômico de sua família empreender atividade comercial no ramo de alimentação:

A gente tá condenado a ser pobre porque nem trabalhar dá. Nem dá de abrir um negócio. Eu e minha esposa queríamos abrir um comércio, vender salgado, suco, açaí, mas quem é que vai parar para comprar num estabelecimento perto do lixo? A rua é boa, é movimentada. Muita gente passa por aqui, mas se eu abrir a vigilância sanitária vem e fecha, porque vai dar rato, vai dar barata... Só que ela fecha o meu estabelecimento, multa a mim, não multa quem faz isso aí. (F. F. A. Entrevista concedida a Xênia de Castro Barbosa, 2016).

A interdição de direito econômico é sentida também por M. C. N, moradora do bairro Nova Esperança

O bairro eu não sei, mas as casas eu acho que sim, se você quiser vender alguma coisa aqui já não dá, eu pelo menos quis montar um negócio ali na frente, mas aqui não dá. Além disso aí tudo (ferro velho ao lado), tem muita sujeira de vala de lá pra cá e passa tudo aqui na frente. Aí pra mim não dá, porque já tem esse lixo aí, sei lá o que tem aí. Pra mim não é bom não. 
Porque se ele fizesse igual antigamente, eu até não me importo. Ele juntava muita coisa na frente da casa dele, agora está ficando bem aqui, já chega até na divisa que é o meu terreno. Desse ano pra cá que ele começou a juntar mais e ele vendia quase todo mês. Ele juntava e vendia. Agora ele só está acumulando, não sei se quer vender tudo de uma vez, mas tá assim, só juntando e jogando aí. (M.C.N. Entrevista concedida a João Baraldi Neto, 2016).

A entrevistada acima também deseja transformar sua residência em ponto de comércio, porém a existência de acúmulo de lixo próximo inviabilizou seu projeto. A presença desses materiais interdita o direito daqueles cidadãos de dispor livremente de seus bens, a saber, de dispor da própria residência transformando-a em ponto comercial. Essas limitações impedem a obtenção de vantagens econômicas que poderia advir com o comércio. Considerando-se que a vida na periferia da cidade é difícil e que muitos de seus moradores vivem com rendimentos modestos, que mal permitem suprir as necessidades básicas, tal interdição configura-se violação ao direito de trabalho.

Em face dos casos em tela, pode-se afirmar que o Estado tem se mostrado omisso. Contudo, assumiu o compromisso público e internacional de zelar pelos direitos econômicos, sociais e culturais, ao acordar com o Pacto Internacional sobre Direitos Econômicos, Sociais e Culturais, adotado pela XXI Sessão da Assembleia-Geral das Nações Unidas, em 19 de dezembro de 1966. Por meio do Decreto 591, de 6 de julho de 1992 (BRASIL, 1992), o Brasil celebrou o compromisso de zelar e promover ações em prol desses direitos.

Segundo a Secretaria de Direitos Humanos da Presidência da República, na publicação Direito à moradia adequada ${ }^{5}$ (2013):

No artigo 6으, a Constituição afirma que são direitos sociais "a educação, a saúde, a alimentação, o trabalho, a moradia, o lazer, a segurança, a previdência social, a proteção à maternidade e à infância, a assistência aos desamparados" E no artigo 182 consta que a política de desenvolvimento urbano tem por objetivo ordenar "[...] as funções sociais da cidade e garantir o bem-estar de seus habitantes", e a propriedade urbana cumpre esta função "quando atende às exigências fundamentais de ordenação da cidade expressas no plano diretor" (BRASIL, 1998, art. 182, par. 2).

Certamente, as funções sociais da cidade não estão sendo garantidas em sua plenitude, o bem-estar, ainda que subjetivo, pode ser presumido que não está de acordo com as necessidades básicas dos cidadãos. No caso de M.C.N, esta teria direito de abrir um comércio com sua moradia, para ampliar sua renda e poder suprir as suas necessidades básicas, mas por circunstâncias alheias à sua vontade, teve o seu Direito violado

5 Disponível em: <http://www.sdh.gov.br/assuntos/bibliotecavirtual/promocao-e-defesa/publicacoes2013/pdfs/direito-a-moradia-adequada>. Acesso em setembro de 2016. 
A defesa dos direitos econômicos se expressa pelo reconhecimento básico do valor do trabalho, entendido como direito social. O Art. 60 do Pacto Internacional sobre Direitos Econômicos, Sociais e Culturais (ONU, 1966), esclarece:

1. Os Estados Partes do presente Pacto reconhecem o direito ao trabalho, que compreende o direito de toda pessoa de ter a possibilidade de ganhar a vida mediante um trabalho livremente escolhido ou aceito, e tomarão medidas apropriadas para salvaguardar esse direito.

2. As medidas que cada Estado Parte do presente Pacto tomará a fim de assegurar o pleno exercício desse direito deverão incluir a orientação e a formação técnica e profissional, a elaboração de programas, normas e técnicas apropriadas para assegurar um desenvolvimento econômico, social e cultural constante e o pleno emprego produtivo em condições que salvaguardem aos indivíduos o gozo das liberdades políticas e econômicas fundamentais.

Ao que parece, nas áreas periféricas de Porto Velho, o desenvolvimento econômico, social e cultural constante, ou seja, em caráter continuado, são uma quimera. A responsabilidade pelo bem-estar e pelo êxito econômico foi transferida aos indivíduos, e estes se veem constrangidos em seu campo de ação em função da degradação do ambiente que os cerca.

A partir dessa realidade local, fica claro o pensamento de Lúcia Lippi Oliveira (2002), que apresenta a cidade ora como espaço de progresso, desenvolvimento e sofisticação do espírito humano, ora como espaço desagregador da subjetividade e que acentua as mazelas sociais.

Sem adentrar no mérito da Psicologia Social, considera-se o padrão de consumo vigente uma estratégia para a inclusão ou exclusão social. Aos que podem consumir é dado integrar determinados grupos e circuitos sociais, e aos que estão apartados ou limitados nessa atividade, é frequente a segregação social. O consumo pode ser percebido ainda como instrumento para a elevação da autoestima e o preenchimento de vazios de ordem existencial.

No ensinamento de Touraine (1994), o consumo implica, para além da satisfação de necessidades vitais, a formação de um sistema simbólico. Consumimos não apenas produtos, mercadorias reais, mas signos por meio dos quais produzimos distinções sociais. Nesse sentido, é possível depreender que tal atividade transcende a dimensão econômica clássica, tornando-se estratégia de acumulação de capital simbólico usado para promover identidades e diferenças, reforçar valores e crenças. Para Cortina,

Hay que intentar comprender que el consumo responde a motivaciones profundas, a crencias sociales, que se expressa em estilos de vida que afectam profundamente a la autoestima de las personas, a sus sentimientos de inferioridad y superioridad, a sua idea de autorrealización, y que grácias a la sagacidad del marketing, se há convertido incluso en una forma de vida (CORTINA, 2002, p. 14). 
Não se pode olvidar, todavia, que o consumo visa a atender às necessidades de reprodução do próprio capital, que opera com o simulacro de atender a necessidades e desejos individuais, autênticos e legítimos. Esses desejos e necessidades que parecem singulares foram produzidos socialmente, e milhares de pessoas também os expressam. Assim, o consumo retroalimenta o processo produtivo e o espaço urbano se apresenta, dialeticamente, como condição e produto desse circuito de produção, distribuição e consumo. Conforme explicaram Pethenchust e Casimiro,

A lógica atual de mercado repousa, em grande parte, no consumo, descarte e reposição constantes dos produtos, e o consumidor constitui-se na mola propulsora de tal economia, sendo a figura central que mantém em movimento contínuo os produtos em circulação. Portanto, em tempos de consumo, descarte e obsolescência programada, enfrentar o problema dos resíduos sólidos importa na criação de mecanismos de incentivo a um consumo ambientalmente responsável, que englobe a diminuição da sua geração, o seu reaproveitamento, reutilização e reciclagem. Em primeiro lugar, cabe a criação de instrumentos que induzam os consumidores a mudar sua visão acerca dos resíduos sólidos, os quais devem deixar de ser encarados como "lixo", sobra e rejeito, para ser compreendidos como parte de um processo circular, no qual os resíduos devem ser reaproveitados e reutilizados, em uma chamada "economia circular". Ou seja, o lixo não deve ser mais encarado pelo consumidor como fim, mas sim como meio, passando de subproduto para produto por excelência em uma lógica ambientalmente responsável (PETHECHUST; CASIMIRO, 2016, p. 304).

Como consumir é desejo humano e não vemos barreiras de contenção às suas formas exageradas, deparamo-nos com um desafio: o de avaliar se as normas regulamentadoras existentes são suficientes e eficazes. Com vistas a subsidiar essa avaliação, teceremos agora algumas considerações sobre o Direito frente à problemática do lixo eletrônico.

No Brasil, a insuficiência de legislação específica e vigente sobre o lixo eletrônico faz com que este seja tratado, na maioria das vezes, na perspectiva dos resíduos sólidos em geral. Há, no entanto, progressivas iniciativas de regulamentação da temática. Projetos de Lei (PL), como o 5860/2009, 2045/2011, 3472/2012, 2940/2015 estão para apreciação na Câmara Federal dos Deputados. Alguns foram arquivados e desarquivados, e colocados como apêndices de outros, evidenciando o desinteresse de determinadas comissões em estabelecer instrumentos de controle sobre esse problema que possui também, potencial de prejudicar a saúde humana, quando descartado de modo incorreto e em áreas impróprias.

O PL 5860/2008 prevê a instituição de normas e procedimentos para a coleta, a reciclagem, o gerenciamento e a destinação final de lixo tecnológico, dentre outras providências. Transita em caráter de urgência na Câmara Federal desde 28 de agosto de 2008, apensado ao PL 4178/98, que foi deferido pelo Plenário. 
O referido Projeto de Lei opera com o conceito de "lixo tecnológico", que é sinônimo de lixo eletroeletrônico:

$\S 1$ 10 Para os efeitos desta Lei, constituem lixo tecnológico os seguintes aparelhos e equipamentos eletroeletrônicos, assim como seus componentes, de uso doméstico, industrial, comercial e de serviços, após o uso pelo consumidor e sujeitos à disposição final:

I- componentes e periféricos de computadores;

II - monitores e televisores;

III - acumuladores de energia (baterias e pilhas);

IV - Produtos magnetizados (CONGRESSO NACIONAL, PL 4178/98).

O PL 5860/2008 prevê a responsabilização das empresas que fabricam, importam e comercializam equipamentos e componentes como os descritos em seu parágrafo 10 e traz ao final um texto de justificativa, em 10 parágrafos concisos e bem redigidos. Nesse texto o proponente argumenta quanto à pertinência de aprovação dessa lei, apresentando informações sobre a quantidade de computadores, telefones celulares e outros produtos descartados, sua obsolescência e perfil de consumo da sociedade brasileira. Aponta também o exemplo da empresa de computadores Dell, que mantém projeto de restauração de computadores usados e ato contínuo, doação para entidades sem fins lucrativos que atuam com a inclusão digital.

Em nossa análise consideramos que o PL 5860/2008 apresenta limitações de informações, como por exemplo, não especificar como as empresas que descumprirem a lei serão responsabilizadas e não prever prazos e metas em relação à coleta, destinação e tratamento do lixo tecnológico. Questiona-se ainda a falta de especificidade do termo "lixo tecnológico", tendo em vista que toda a história humana é marcada pelo desenvolvimento de tecnologias, desde os primórdios até os tempos mais recentes.

No ensinamento de Cardoso (2001) e Acevedo Díaz (2002), não se separa a história humana da história da técnica, pois esta é produzida simultaneamente ao processo de adaptação e evolução das sociedades. Assim, todos os instrumentos produzidos com a intenção de interferir ou modificar dado aspecto do mundo é tecnologia, e tudo o que é descartado desse processo após o uso social, é lixo tecnológico. Dado o exposto, considera-se adequada a adoção de nomenclaturas mais precisas. O problema da generalização conceitual do PL em análise foi minimizado, entretanto, na medida em que o proponente exemplificou os tipos de lixo tecnológico aos quais o projeto se refere.

O PL 2045/2011 dispôs sobre a coleta e a destinação ambientalmente adequada de resíduos tecnológicos. Ou seja, aborda a mesma questão que o PL 5860/2008, e como este 
também está aguardando parecer do Relator na Comissão de Constituição e Justiça e de Cidadania (CCJC) da Câmara Federal.

O texto é de autoria do Deputado Penna (PV/SP) e tramita desde 17/08/2011 e traz, do ponto de vista legal, maior riqueza de informações que o primeiro.

O Artigo 2o do PL 2045/2011 proíbe o descarte de qualquer tipo de lixo eletrônico no lixo domiciliar, comercial ou industrial, obrigando as empresas fabricantes e comerciantes a receberem reversamente esses produtos e darem destino correto a eles. O texto não prevê exceções, assim, nem mesmo uma pilha pequena, de uso doméstico, poderia ser descartada em lixeira comum. 0 caráter contundente sugere amplo comprometimento com o meio ambiental, além de responsabilização das pessoas jurídicas pela coleta, reciclagem e descarte correto dos resíduos, quando não for mais possível sua incorporação nos processos de reaproveitamento.

Quanto à responsabilidade das Pessoas Jurídicas o texto assim as define:

Art. 3 - Constitui responsabilidade das pessoas jurídicas de direito privado que fabricam, importam e comercializam produtos que gerem resíduos tecnológicos a coleta e a destinação final ambientalmente adequadas, em especial:

I - Operacionalizar o sistema de retorno dos produtos após o uso pelo consumidor;

II - Viabilizar postos de entrega de produtos usados;

III - conscientizar o consumidor de produtos tecnológicos sobre os riscos à saúde e ao meio ambiente decorrentes do seu descarte inadequado;

IV - Promover a reutilização, a reciclagem, a recuperação ou a disposição final ambientalmente adequada, de modo a evitar riscos à saúde pública e à segurança e a minimizar os impactos ambientais adversos (CONGRESSO NACIONAL, PL 2045/2011).

O parágrafo 1을 do Artigo 3으 do PL supracitado enuncia a conceituação do que entende por resíduos tecnológicos.

I - pilhas e baterias portáteis, baterias chumbo-ácido, automotivas e industriais, pilhas e baterias dos sistemas eletroquímicos níquel-cádmio e óxido de mercúrio e de aparelhos de telefones celulares;

II - Computadores e seus equipamentos periféricos, incluindo monitores de vídeo, telas, displays, impressoras, teclados, mouses, autofalantes, drivers, modens, câmeras e outros;

III - televisores e outros equipamentos que contenham tubos de raios catódicos;

IV - eletrodomésticos e eletroeletrônicos que contenham metais pesados ou outras substâncias tóxicas;

V - Lâmpadas fluorescentes, de vapor de sódio e mercúrio e de luz mista (CONGRESSO NACIONAL, PL 2045/2011).

Esclarece-se que os produtos enumerados se tornam resíduos após o uso pelo consumidor, antes do uso são somente mercadorias, produtos disponíveis no mercado. 
O PL 2045/2011, diferente do PL 5860/2008 não apresenta texto de justificativa nem nenhum outro dado que motive a reflexão dos parlamentares ou estimule a aceleração dos trâmites de apreciação. Esses elementos ausentes não são obrigatórios e não retiram o mérito da proposta.

1. O PL 3472/2012 segue em apreciação em regime ordinário no Congresso Nacional e encontra-se aguardando parecer do relator na Comissão de Meio Ambiente e Desenvolvimento Sustentável (CMADS). O Projeto é uma proposta de Fernando Jordão (PMDB/RJ) e tem como afã tornar obrigatória a utilização de materiais reciclados em produtos eletroeletrônicos e eletrodomésticos.

2. O documenta apresenta apenas três artigos, transcritos abaixo:

Art. 1‥ Esta Lei dispõe sobre a obrigatoriedade de utilização por parte da indústria, de materiais recicláveis na fabricação de componentes eletroeletrônicos e eletrodomésticos nos seguintes percentuais:

a) Do primeiro ao quinto ano, no mínimo 15\%;

b) Do sexto ano ao décimo ano, no mínimo 25\%;

c) Do décimo primeiro ano ao décimo quinto ano, no mínimo $35 \%$.

Art. 2ㅇ. É obrigatória a utilização de um selo nos produtos, informando que o produto utiliza materiais recicláveis em sua composição.

Art. 3‥ Esta lei entra em vigor na data de sua publicação (CONGRESSO NACIONAL, PL 3472/2012)

Apenso ao PL 3472/2012 segue uma Justificação, de extensão de uma lauda, em que o proponente solicita dos demais parlamentares a pronta aprovação do texto apresentado. Vale destacar que esse texto de Justificativa apresenta várias inadequações do ponto de vista formal da Língua Portuguesa e mais parece a transcrição de um discurso oral do que de um texto redigido intencionalmente para servir de base para discussão tão relevante. O documento carece ainda de precisão dos dados, no entanto, sabe-se que o tom apelativo usado pelo parlamentar do PL em questão - e não só por ele -, costuma ser eficiente, no sentido de conseguir convencer os pares a votarem pela aprovação. Ainda assim, ressalta-se, o PL 3472 ainda não recebeu decisão definitiva.

O Projeto de Lei 2940/2015, que estima estabelecer normas para o gerenciamento e destinação final do lixo eletrônico foi apresentado ao Congresso Nacional na data de nove de setembro de 2015, pelo Deputado Felipe Bornier (PSD/RJ) e foi apensado ao PL 2045/2011, já mencionado. O PL em resenha revelou-se um dos mais claros e completos que tivemos a oportunidade de analisar. Seu texto é rico em detalhes e a justificativa apensa a ele é um texto provocador, bem fundamentado e que apresenta argumentos consolidados sobre os perigos do lixo eletrônico. Retoma ainda a Convenção de Basiléia-, da qual o Brasil é signatário-, e apresenta 
informações polêmicas a respeito do comércio internacional de lixo eletrônico, da insuficiência de fiscalização desse e de outros ilícitos concernentes à matéria.

Parte considerável das ideias expressas nos PLs anteriores se repete neste, todavia, este apresenta algumas diferenças significativas, como por exemplo, o fato de trazer expresso, em seu Art. 2o a preocupação com a destinação final do lixo eletroeletrônico: "Art. 2o O lixo eletrônico deve receber uma destinação final adequada que não provoque danos ou impactos negativos ao meio ambiente e à sociedade". (CONGRESSO NACIONAL, PL 2940/2005). Vai além, informando como deve ser a destinação final correta, após definir o que é lixo eletrônico:

Art. 3 Entende-se por lixo eletrônico todo resíduo material produzido pelo descarte de equipamentos eletrônicos de uso doméstico, industrial, comercial e de serviços, que estejam em desuso e sujeitos a disposição final. Art. 4 A responsabilidade pela destinação final do lixo eletrônico é solidária entre os responsáveis pela produção, comercialização e importação do produto e de seus componentes eletroeletrônicos.

Art. 5ㅇ A destinação final do lixo eletrônico ambientalmente adequada, darse-á mediante:

1. Processos de reciclagem e aproveitamento do produto ou de seus componentes para sua finalidade original ou diversa;

2. Reutilização total ou parcial de seus componentes tecnológicos;

3. Disposição final adequada e neutralização de seus componentes tecnológicos equiparados a lixo químico (CONGRESSO NACIONAL, PL 2940/2005).

O texto ressalta que a destinação final do lixo eletrônico deve obedecer à legislação ambiental, de saúde e segurança pública, em observância às instruções normativas dos órgãos públicos responsáveis. Exige, no parágrafo 20 do Art. 5ำ, que a destinação final de equipamentos e componentes eletroeletrônicos com metais pesados ou substâncias tóxicas seja precedida de licença ambiental do órgão competente - que poderá exigir EIA - Estudo de Impacto Ambiental.

No que diz respeito à empresa responsável pela fabricação, importação ou comercialização de EEE - Equipamentos Eletroeletrônicos exige-se a manutenção de postos de coleta dos produtos e componentes descartados pelos consumidores. Após o recolhimento do lixo eletrônico as empresas deverão ainda promover a destinação ambientalmente correta, que significa observar a legislação sanitária e de segurança.

As penalidades previstas para quem descumprir a legislação (caso seja sancionada), estão previstas no Artigo 8o do PL 2940/2005:

Art. $8^{\circ} \mathrm{O}$ descumprimento do disposto nesta lei, sujeitará o infrator as seguintes penalidades:

I - Advertência

II - Multa 
III - proibição para fabricar, importar ou comercializar produto ou componente eletroeletrônico sujeito às normas desta lei.

$\S 1^{\circ} \mathrm{Em}$ caso de reincidência, o valor da multa será dobrado e a penalidade agravada (CONGRESSO NACIONAL, PL 2940/2005).

Julga-se positiva a estipulação de punições aos infratores, bem como a responsabilização do Poder Público, prevista no Artigo 7o, em razão de atos omissivos ou comissivos. O PL indica ainda que o Poder Público de cada esfera é competente e responsável pela fiscalização em seu âmbito de atuação, e proíbe veementemente a remessa, comércio, doação, descarte e tráfico de lixo eletroeletrônico:

Art. $9^{\circ}$ É terminantemente proibida à remessa, o envio, a venda, o descarte e o tráfico de lixo eletrônico entre países, estados e municípios.

$\S 1^{\circ}$ Cumpre ao Poder Público competente a fiscalização e a prevenção deste tipo de crime, com a adoção das medidas necessárias.

$\S 2^{\circ}$ A observância do disposto no caput deste artigo é considerada obrigação de relevante interesse ambiental, para efeitos do art. 68 da Lei $n^{\circ}$. 9.605, de 1998, sem prejuízo da aplicação de outras sanções cabíveis na esfera penal e administrativa.

Ao mencionar a problemática da movimentação transfronteiriça de lixo eletroeletrônico o autor aponta para questão já proibida pela Lei 12.305/2010 (Política Nacional de Resíduos Sólidos), em seu Artigo 49: “Art. 49. É proibida a importação de resíduos sólidos perigosos e rejeitos, bem como de resíduos sólidos cujas características causem dano ao meio ambiente, à saúde pública e animal e à sanidade vegetal, ainda que para tratamento, reforma, reuso, reutilização ou recuperação". Essa problemática foi levantada, anteriormente, pela Convenção de Basileia (1989). Esta, por sua vez, tem como intuito coibir o comércio ilegal de resíduos de eletroeletrônicos e intensificar a cooperação internacional, com fito na gestão ambiental compartilhada desses resíduos.

No Brasil, a Convenção de Basiléia foi internalizada por meio do Decreto n. 875, de 19 de julho de 1993, e regulamentada, também, pela Resolução CONAMA n. 452, 02 de julho de 2012.

A progressão dessas legislações, assim como a proposição dos PL analisados indicam a preocupação do Estado brasileiro com a problemática do lixo eletrônico e a pertinência do assunto, assim como nos fazem pensar nas dificuldades em aprová-las e torná-las efetivas.

Essa preocupação expressa pelo Estado brasileiro em criar leis não tem se feito notar, contudo, no município de Porto Velho. O município, que comemorou seu primeiro centenário em 2014, não dispõe de instrumento regulatório sobre o lixo eletrônico e este tipo de resíduo nem aparece de forma específica em seu Plano Municipal de Gestão de Resíduos Sólidos ou em seus relatórios de Qualidade Ambiental. A Lei Complementar n. 546/2014 ainda não foi regulamentada. 
Diante dessa ausência documental, empenhamo-nos em observações em campo, nas quais pudemos constatar descarte impróprio de lixo eletroeletrônico em bairros periféricos da cidade, como o bairro Nova Esperança e o Lagoinha, bem como em região central (Mocambo e Triângulo). Vimos descarte de monitor de computador inclusive no Rio Madeira, rio utilizado por ribeirinhos para atividades de pesca.

Em Porto Velho, a Lei Complementar 546/2014 ainda não foi sancionada, mas de antemão se informa que os resíduos sólidos domésticos, descritos em seu Art. 1ำ, III são bastante genéricos: "os provenientes de imóveis residenciais de qualquer natureza". A única classificação que se assemelha às características do lixo eletrônico seria a dos "resíduos sólidos diferenciados com tratamentos específicos", conforme Art. 1ำ, IV, no que reporta a pilhas, baterias e resíduos radioativos. Os materiais ainda inteiros, como celulares e computadores não possuem um direcionamento previsto na lei.

O Art. 4ำ da Lei complementar no 546/2014, esclarece que é proibido o lançamento de resíduos sólidos em terrenos vagos, públicos ou privados. Em algumas partes do município é evidente o despejo de resíduos sólidos em ambientes abertos, sejam eles públicos ou privados. A capital recebe a média de 15 toneladas de resíduos sólidos por mês ${ }^{6}$. Não há coleta seletiva de lixo no município, todos possuem o mesmo destino.

A falta de nomenclaturas específicas dificulta o encaixe de determinados tipos de lixo, como o eletrônico. O meio ambiente, contudo, carece de aplicações jurídicas e administrativas precisas.

Mais grave do que o descarte impróprio desse tipo de lixo, vimos pessoas vivendo junto a ele, registramos a indignação de moradores dessas adjacências diante da ausência do Estado e aventamos a hipótese de casos de Transtorno de Acumulação Compulsiva e Síndrome de Diógenes - o que não confirmamos, por falta de competência diagnóstica na área.

A ausência de legislação municipal sobre o e-lixo e o conhecimento empírico dos pesquisadores sobre a realidade urbana possibilita afirmar que Porto Velho caminha na contramão da regulamentação e fiscalização dos problemas concernentes ao lixo eletrônico. E esse hiato de normas e informações parece atender a determinados objetivos de classe e concepções equivocadas sobre o valor do meio ambiente e sua capacidade de resiliência, consolidando aliança com o Capital em detrimento dos interesses coletivos.

\footnotetext{
${ }^{6}$ Disponível em:< http://g1.globo.com/ro/rondonia/noticia/2013/04/plano-de-residuos-solidos-comeca-serdiscutido-em-porto-velho.html>. Acesso em 16. Mai., 2016.
} 
Tal situação, típica de países de desenvolvimento tardio, ressalta os laços que nos mantém na posição subalterna de exportador de matérias-primas e de mão de obra de baixa qualificação, e importador de produtos industrializados. Posição que mantemos, a despeito das lutas por independência e descolonização cultural.

Ao se analisar a legislação concernente ao assunto, tanto a da esfera nacional quanto a local, sentiu-se necessidade de abordagem mais específica sobre o lixo eletroeletrônico, tendo em vista a especificidade de seu caráter, o aumento de sua produção e descarte e a pouca quantidade de informações disponíveis sobre o assunto em linguagem acessível aos consumidores.

Os aparelhos eletroeletrônicos são compostos, em sua maioria, por metais pesados e substâncias tóxicas. Quando entram em contato com a natureza, essas substâncias geram graves problemas ambientais, podendo, inclusive, resultar em danos à saúde humana, conforme Quadro 1.

\section{Quadro 1: Elementos químicos encontrados em Lixo Eletroeletrônico e seus efeitos sobre a saúde, Brasil, 2016}

\begin{tabular}{|c|c|c|}
\hline Elemento & Onde é encontrado & Danos causados \\
\hline Chumbo & $\begin{array}{c}\text { Computadores, celulares e } \\
\text { televisões }\end{array}$ & Danos aos sistemas nervoso e sanguíneo. \\
\hline Mercúrio & $\begin{array}{c}\text { Computadores, monitores e } \\
\text { TVs de tela plana }\end{array}$ & Danos cerebrais e ao fígado. \\
\hline Cádmio & $\begin{array}{c}\text { Computadores, monitores } \\
\text { antigos e baterias de } \\
\text { notebooks }\end{array}$ & $\begin{array}{l}\text { Envenenamento, danos aos ossos, rins e } \\
\text { pulmões. }\end{array}$ \\
\hline Arsênio & Celulares & $\begin{array}{c}\text { Doenças de pele, prejudica o sistema nervoso e } \\
\text { pode causar câncer no pulmão. }\end{array}$ \\
\hline Berílio & Computadores e celulares & Câncer no pulmão. \\
\hline $\begin{array}{l}\text { Retardante de } \\
\text { chamas (BRT) }\end{array}$ & $\begin{array}{c}\text { Diversos componentes } \\
\text { eletrônicos para prevenção } \\
\text { de incêndios }\end{array}$ & Desordens hormonais, nervosas e pulmonares. \\
\hline PVC & $\begin{array}{c}\text { Fios, para isolamento } \\
\text { elétrico }\end{array}$ & $\begin{array}{c}\text { Se queimado e inalado, pode causar problemas } \\
\text { respiratórios. }\end{array}$ \\
\hline Lítio & Pilhas e baterias & Afeta o sistema nervoso central, gerando visão \\
\hline
\end{tabular}

Revista de Direito da Cidade, vol. 09, no 1. ISSN 2317-7721 pp. 276-312 306 


\begin{tabular}{|c|c|c|}
\hline & & $\begin{array}{l}\text { turva, ruídos nos ouvidos, vertigens, debilidade e } \\
\text { tremores }\end{array}$ \\
\hline Níquel & Pilhas e baterias & $\begin{array}{l}\text { Dermatites, distúrbios respiratórios, gengivites, } \\
\text { "Sarna de níquel", efeitos carcinogênicos, cirrose } \\
\text { e insuficiência renal. }\end{array}$ \\
\hline Zinco & Pilhas e baterias & Vômitos e diarreias. \\
\hline $\begin{array}{l}\text { Cobalto e } \\
\text { compostos }\end{array}$ & Baterias de lítio & $\begin{array}{l}\text { "Sarna do cobalto", conjuntivite, bronquite e } \\
\text { asma. }\end{array}$ \\
\hline $\begin{array}{l}\text { Bióxido de } \\
\text { manganês }\end{array}$ & Pilhas alcalinas & $\begin{array}{l}\text { Anemia, dores abdominais, vômitos, crises } \\
\text { nervosas, dores de cabeça, seborréia, } \\
\text { impotência, tremor nas mãos, perturbação } \\
\text { emocional. }\end{array}$ \\
\hline
\end{tabular}

Fonte: Adaptado de Hahn et al. (2015).

Ante os riscos que oferece à saúde e ao equilíbrio dos ecossistemas o lixo eletrônico precisa ser discutido de forma mais responsável, além de ser recolhido e tratado de modo responsável, a fim de se evitar contaminação. O Estado, visando à proteção coletiva, deve, através de seus institutos, agir, inclusive de forma coercitiva, visando alcançar objetivo de levar qualidade de vida a todos (NUNES, 2007).

Vale lembrar que muitas vezes o perigo não é aparente e os efeitos causados pelos elementos descritos no Quadro 1 são retardantes, crônicos e bioacumuláveis.

\section{CONSIDERAÇÕES FINAIS}

A grande quantidade de lixo eletrônico descartada anualmente em todo o mundo é sintomática da crise do modo de produção e de consumo no qual estamos inseridos.

O descarte incorreto desses produtos pode resultar em impactos negativos sobre o meio ambiente e a saúde humana, ocasionando problemas que vão desde infecções cutâneas até neoplasias e degenerações neurológicas. Apesar da gravidade do problema, faltam informações capazes de esclarecer aos consumidores sobre os riscos que seu comportamento pode causar e falta legislação específica sobre o assunto, tanto na esfera nacional quanto na esfera municipal (em Porto Velho). 
Esta pesquisa oferece resultados capazes de contribuir com a situação atual dos resíduos sólidos no município de Porto Velho, pois descreve a realidade social dos habitantes através das entrevistas e das análises dos dispositivos legais, hierarquizados, respectivamente, com uma lei federal, até a disposição da legislação municipal.

Na esfera nacional há Lei 12.305/2010, que aborda o lixo eletrônico de modo indireto, sob a classificação de "resíduos sólidos", as Resoluções CONAMA 263/1999, 401/2008 e 452/2012 e pelo menos cinco PL em tramitação, que abordam o assunto. Não obstante a essa movimentação nacional que expressa preocupação com a sanidade ambiental e da população, em Porto Velho constatou-se vazio documental e jurídico, indicando postura omissiva.

Em 2014 houve, nesta cidade, iniciativa do Legislativo municipal em regular o assunto, mas a proposta foi vetada pelo Executivo, possivelmente por falta de condições de cumprir o que seria sua parte na gestão dos RSU. De modo geral, prevalecem, todavia, considerações genéricas acerca dos RS e do lixo tecnológico, o que dificulta um enfrentamento mais consequente do problema analisado.

A existência de RS em geral, de lixo eletroeletrônico, em particular, causa grande desconforto aos moradores de Porto Velho que residem nas adjacências desses depósitos irregulares. O efeito desses resíduos impacta não só a saúde da população, como a apreciação estética da paisagem urbana, o valor das propriedades localizadas próximas a eles, e impacta também o direito econômico de empreender indústria ou comércio, em função das condições insalubres geradas.

Sinteticamente, o não enfrentamento de forma contundente e responsável do problema dos resíduos sólidos e eletroeletrônicos fere o direito à cidade, indicando ainda que o Estatuto da Cidade encontra dificuldades em ser efetivado, mesmo passado mais de 15 anos de sua promulgação.

De modo amplo, o lixo eletrônico, ao comprometer o meio ambiente urbano, interfere no direito à cidade e contribui para reproduzir uma estrutura social de exclusão e segregação. Embora exista lixo depositado nas áreas centrais, são as áreas periféricas as que mais sofrem com esse tipo de problema, o que contribui para a manutenção de estereótipos sobre a população residente nessas áreas, a interdição de seus direitos, a não valorização de suas propriedades e a vexação social.

A cidade, como espaço utópico e em construção, demanda o empenho coletivo em prol da reformulação de suas políticas públicas, da promoção do bem-estar e da ampliação e salvaguarda 
dos direitos humanos, dentre os quais o de um meio ambiente saudável para as gerações presentes e futuras. Construir essa cidade melhor demanda ação e reflexão, e a produção e o consumo estão entre os elementos que mais urgentemente precisam ser analisados criticamente. É preciso uma abordagem dialética para avaliar custos e benefícios e um espírito moderno para ousar experimentar novos modos de vida, fazer novos descobrimentos, redefinir valores socialmente cristalizados.

Em Porto Velho, se faz necessário ainda a superação de uma cultura exploratória e despreocupada com o meio ambiente, cultura essa que perpassou sua formação geo-histórica e constitui até hoje parte relevante de sua economia - economia de fronteira. Essa cidade foi formada a partir de ciclos de colonização pautados em interesses exógenos à sua população tradicional e conduzidos por pessoas e empresas que não tinham outro propósito senão explorar os recursos do lugar e em seguida retornar para suas cidades de origem, levando consigo as vantagens obtidas. Falta, portanto, compromisso com a vida do município, definição de projetos, disposição em construir uma nova história, mais ética e responsável do ponto de vista ambiental.

Considera-se pertinente, ainda, em relação à cidade de Porto Velho, a apresentação de um projeto de Lei específico para o lixo eletroeletrônico, ao lado do fortalecimento do diálogo entre Poder Público e Sociedade, Executivo, Legislativo e Judiciário, e da ampliação da fiscalização ambiental.

Recomenda-se também a organização de novos estudos sobre o assunto em foco, de modo a ampliar o conhecimento sobre o problema.

\section{REFERÊNCIAS}

ACEVEDO DÍAZ, J. A. ¿Qué puede aportar la Historia de la Tecnología a la Educación CTS? Biblioteca Digital da OEI (Organização de Estados Iberoamericanos para a Educação, a Ciência e a Cultura, 2002. Disponível em < http://www.campusoei.org >. Acesso em 14 set. 2016.

ÂNGELO, M. Direitos humanos: São Paulo: Editora de Direito, 1998.

ARAÚJO, P. Política de Resíduos Sólidos apresenta resultados em 4 anos. Informativo Eletrônico do Ministério do Meio Ambiente. Disponível em: <http://www.mma.gov.br/informma/item/10272pol\%C3\%ADtica-de-res\%C3\%ADduos-s\%C3\%B3lidos-apresenta-resultados-em-4-anos> Acesso em: 05 ago. 2014

BARBOSA, X. C. Território e saúde: políticas públicas de combate à dengue em Porto Velho/RO, 1999-2013. Curitiba: UFPR (Programa de Doutorado em Geografia). Tese, vol. 1, 2015. 
BARROSO, L.R. Curso de Direito Constitucional contemporâneo. 2ª. ed. São Paulo: Saraiva, 2010.

BAUMAN, Z. Modernidade líquida. Rio de Janeiro: Zahar Ed., 2001.

Vidas desperdiçadas. Rio de Janeiro: Zahar Ed., 2005.

BECK, U. Risk society. Towards a new modernity. Londres: Sage Publications, 1992. A política na sociedade de risco. Trad. de Estevão Bosco, Ideias, v. 02, n. 01, 2010. World risk society. Cambridge: Polity Press, 1999.

BRASIL. República Federativa do Brasil. Constituição da República Federativa do Brasil. Brasília, DF: Senado Federal, 1988.

República Federativa do Brasil. Lei no 12.305, 2010 - Institui a Política Nacional de Resíduos Sólidos. Brasília: 2010.

República Federativa do Brasil. Decreto 591, de 6 de julho de 1992. Brasília: 1992.

República Federativa do Brasil. Lei. 10.257, de 10 de julho de 2001. Brasília: 2001.

República Federativa do Brasil. Decreto n 875, de 19 de julho de 1993. Disponível em: http://www.planalto.gov.br/ccivil_03/decreto/D0875.htm\#_blank Acesso em 13 set. 2016. República Federativa do Brasil. Lei n. 11.105, de 24 de março de 2005. Brasília: 2001.

Secretaria de Direitos Humanos da Presidência da República. Direito à moradia adequada. Brasília: Coordenação Geral de Educação em SDH/PR, Direitos Humanos, Secretaria Nacional de Promoção e Defesa dos Direitos Humanos, 2013. Disponível em: $<$ http://www.sdh.gov.br/assuntos/bibliotecavirtual/promocao-e-defesa/publicacoes-

2013/pdfs/direito-a-moradia-adequada>. Acesso 13 set. de 2016.

CARDOSO, T. F. L. Sociedade e Desenvolvimento Tecnológico: Uma Abordagem Histórica. In: Grinspun, M.P.S.Z. (org.). Educação Tecnológica: Desafios e Pespectivas. São Paulo. Cortez. 2001. p. 183-225.

CONAMA. Conselho Nacional do Meio Ambiente. Resolução n. 452, 02 de julho de 2012. Disponível em: http://www.mma.gov.br/port/conama/legiabre.cfm?codlegi=676 Acesso em 13 set. 2016.

CONGRESSO NACIONAL. Projeto de Lei 5860/2009. Disponível em: < http://www.camara.gov.br/proposicoesWeb/fichadetramitacao?idProposicao=447029> Acesso em 12 set. 2016

Projeto de Lei 2949/2015. Disponível em: http://www.camara.gov.br/proposicoesWeb/fichadetramitacao?idProposicao=1713504 Acesso em 12 set. 2016.

Projeto de Lei 3472/2012. Disponível em: http://www.camara.gov.br/proposicoesWeb/fichadetramitacao?idProposicao=537785 Acesso em 12 set. 2016

Projeto de Lei 2045/2011. Disponível em: http://www.camara.gov.br/proposicoesWeb/fichadetramitacao?idProposicao=515927 Acesso em 12 set. 2016

CORTINA, A. Por uma ética del consumo. Madrid: Santillana Ed., 2002.

FIERO. Federação das Indústrias de Rondônia. Rondônia: economia e desenvolvimento. Porto Velho: Edição do autor, 2011. 
FOUCAULT, M. A Ordem do Discurso - Aula inaugural no College de France. Pronunciada em 2 dezembro de 1970. São Paulo. Ed. Loyola: 1996.

As palavras e as coisas. São Paulo: Martins Fontes, 2000.

GADAMER, H. Verdade e Método: traços fundamentais de uma Hermenêutica filosófica. 1 ed. Petrópolis: Vozes, 1997.

GIL, A. C. Como elaborar projetos de pesquisa. São Paulo: Atlas, 2008.

HAHN, A.L et. al. Alternativas para o Lixo Tecnológico. UFSM, 2015. Disponível em: http://wwwusr.inf.ufsm.br/ pablo/e-lixo/contatos.html. Acesso em: janeiro de 2016.

HARVEY, D. O Direito à Cidade. Lutas Sociais, São Paulo, n.29, p.73-89, jul. /dez. 2012. Disponível em: < http://www4.pucsp.br/neils/downloads/neils-revista-29-port/david-harvey.pdf> Acesso em 08/09/2016.

HESPANHOL, R. A. M. Campo e cidade, rural e urbano no Brasil contemporâneo. Mercator, Fortaleza, v. 12, número especial (2)., p. 103-112, set. 2013.

IBGE. Instituto Brasileiro de Geografia e Estatística. Censo Demográfico 2010. Brasília: 2010.

KONDER, L. O que é dialética. São Paulo: Brasiliense, Primeiros Passos, 1981.

LEFEBVRE, H. O direito à cidade. São Paulo: Centauro, 2001. (Tradução: Rubens Eduardo Frias).

MAZIÉRE, F. A Análise do Discurso. São Paulo: Parábola, 2007.

NUNES, R. Princípios do Direito Ambiental. Boletim Jurídico, Uberaba/MG, a. 4, o 170. Disponível em: <http://www.boletimjuridico.com.br/doutrina/texto.asp?id=1147>. Acesso em: 11 out. 2007.

OLIVEIRA, L. L. Cidade: história e desafios. Rio de Janeiro: Ed. Fundação Getúlio Vargas, 2002.

ONU. Organização das Nações Unidas. Relatório Perspectivas da Urbanização (Word urbanization prospects). Department od Economic and Social Affairs, Populations Division, 2014.

Assembleia Geral da Organização das Nações Unidas. Pacto Internacional sobre Direitos Econômicos, Sociais e Culturais, 1966.

PETHECHUST, E.R.B; CASIMIRO, L.M.S.M. O direito à cidade: eficiência da Política Nacional de Resíduos Sólidos à luz da análise econômica do Direito. Revista de Direito da Cidade, vol. 08, no 1. pp. 294-307. 2016. Disponível em: <http://www.epublicacoes.uerj.br/index.php/rdc/article/view/19807/15658>. Acesso em jul. 2016.

PORTO VELHO. Câmara Municipal de Porto Velho. Lei Complementar n. 546, de 22 de outubro de 2014. Porto Velho, 2014.

SANTOS, B. S. O Estado, o Direito e a questão urbana. Revista Crítica de Ciências Sociais, 9, 1982. 
SPITZCOVSKY, D. ONU lança primeiro mapa global de lixo eletrônico. Planeta Sustentável, 17/12/2013. Disponível em: http://planetasustentavel.abril.com.br/noticia/lixo/onu-lancaprimeiro-mapa-global-lixo-eletronico-e-lixo-world-map-763469.shtml Acesso em 15 jun. 2016.

TOURAINE, A. Crítica da Modernidade. Petrópolis: Vozes, 1994.

WOLKMER, A. C. Introdução aos fundamentos de uma teoria geral dos "novos" direitos. Revista Jurídica, vol. 2, n; 31, 2013, pp. 122-148.

Trabalho enviado em 27 de julho de 2016.

Aceito em 20 de setembro de 2016. 